\title{
Effect of chlorhexidine chip as an adjunct in non-surgical management of periodontal pockets: a meta-analysis
}

\author{
Lili Ma ${ }^{1}$ and Xiuchun Diao ${ }^{2^{*}}$ (i)
}

\begin{abstract}
Background: The aim of this meta-analysis was to evaluate the difference in treatment outcomes between subgingival placement of chlorhexidine chip (CHX chip) in adjunct to scaling and root planing (SRP) and SRP alone for the management of periodontal pockets in patients suffering from chronic periodontitis.

Methods: We searched the MEDLINE (PubMed), SCOPUS and CENTRAL databases and identified 15 randomized clinical trials published within the last decade (2007-2019): 9 with split-mouth design and 6 with parallel study design. We extracted data and performed both qualitative and quantitative syntheses. The primary outcomes assessed were gain in clinical attachment level (CAL), reduction in probing pocket depth (PPD), improvement in gingival inflammation, and results of microbiological assays.
\end{abstract}

Results: We used meta-analysis plots to assess all the clinical outcomes. The mean differences in PPD reductions at 1 month (MD 0.63), 3 months (MD 0.69), and 6 months (MD 0.75); and the CAL gains at 1 month (MD 0.54), 3 months (MD 0.64), and 6 months (MD 0.68) showed more favorable responses in sites treated with the CHX chip as an adjuvant to SRP, than in sites treated with SRP alone.

Conclusion: SRP with adjunctive CHX chips showed better clinical outcomes than SRP alone for the management of periodontal pockets in patients with chronic periodontitis.

Keywords: Chlorhexidine Chip, Chronic periodontitis, Scaling and root Planing, Periodontal pockets

\section{Background}

Periodontal disease is characterized by inflammation of tooth supporting structures, and is primarily caused by the presence of dental plaque and calculus [1]. The irreversible periodontium damage caused by noxious substances produced by the plaque micro-flora and the inevitable host response by cytokine release lead to disease progression during chronic periodontitis [2]. The goal of periodontal treatment is to render the tooth surface free from dental plaque and calculus, thereby reducing or

\footnotetext{
*Correspondence: Diaoxiuchun123@outlook.com

${ }^{2}$ Department of stomatology, Zaozhuang Hospital of Traditional Chinese

Medicine, 2666 Taihangshan Road, Xuecheng District, Zaozhuang, Shandong 277000, P.R. China

Full list of author information is available at the end of the article
}

eradicating periodontal pathogens and allowing periodontal tissues to restore their health [3]. Treatment is primarily achieved by nonsurgical methods of periodontal therapy [4-7].

Scaling and root planing (SRP) is an effective nonsurgical periodontal therapy for chronic periodontitis at its early stages [8]. However, the operator's accessibility to clean deep periodontal pockets remains limited in cases of furcation, multi-rooted teeth, developmental grooves, root concavities, mal-occlusion, and inter-proximal areas. This limitation to proper instrumentation in inaccessible areas compromises the effectiveness of SRP [9]. This has led to the use of antimicrobials as an adjunct to SRP, assuming that such agents would aid to treat the dysbiosis in these

(c) The Author(s). 2020 Open Access This article is licensed under a Creative Commons Attribution 4.0 International License, which permits use, sharing, adaptation, distribution and reproduction in any medium or format, as long as you give appropriate credit to the original author(s) and the source, provide a link to the Creative Commons licence, and indicate if changes were made. The images or other third party material in this article are included in the article's Creative Commons licence, unless indicated otherwise in a credit line to the material. If material is not included in the article's Creative Commons licence and your intended use is not permitted by statutory regulation or exceeds the permitted use, you will need to obtain permission directly from the copyright holder. To view a copy of this licence, visit http://creativecommons.org/licenses/by/4.0/. The Creative Commons Public Domain Dedication waiver (http://creativecommons.org/publicdomain/zero/1.0/) applies to the data made available in this article, unless otherwise stated in a credit line to the data. 
inaccessible areas and help prevent microbial colonization to promote clinical improvements. Studies have shown that local as well as systemic anti-microbial agents have a beneficial effect on non-surgical periodontal therapy [10, 11]. Locally administered antimicrobial agents are, however, preferred since they are associated with less systemic side-effects than systemic antimicrobials. A number of local antimicrobial agents have been advocated as adjuvants for management of periodontal diseases [12]. But, attempts to administer these agents locally inside the periodontal pocket were limited by lack of retention and inability to achieve adequate inhibitory concentrations in the gingival crevicular fluid $[13,14]$.

Chlorhexidine (CHX) is a bis-biguanide molecule made up of two (p-chlorophenyl) guanide units linked by a hexamethylene bridge. It is a potent anti-infective and antibacterial mouth-rinse agent used as a prophylactic and therapeutic measure against periodontal disease [15]. Despite having a high substantivity as compared to other antimicrobial agents, the subgingival availability of $\mathrm{CHX}$ is limited and questionable when used as mouth-wash [16].

Local CHX delivery has shown clinical benefits when compared to the use of mouth rinse [17]. A CHX chip is a resorbable chip with $2.5 \mathrm{mg}$ of $\mathrm{CHX}$ embedded in a cross-linked hydrolyzed gelatin matrix. When subgingivally delivered into deep periodontal pockets, the chip releases a controlled amount of CHX with simultaneous biodegradation over a 1 week period providing a CHX concentration lower than $125 \mathrm{mg} / \mathrm{ml}$ to the gingival sulcular fluid [18].

A systematic review on adjunctive use of the CHX chip with SRP failed to provide conclusions in terms of the chip's treatment effectiveness due to inadequate numbers of studies available at the time [19]. Six studies included in the systematic review were of low quality, had high heterogeneity and lacked information on allocation concealment and follow-ups. With publication of several studies since then, there is a need for updated evidence on the subject. Therefore, the purpose of this systematic review and meta-analysis was to analyze the literature to assess the efficacy of sub-gingival CHX chip when used as adjunct with SRP for non-surgical treatment of periodontal pockets in patients with chronic periodontitis.

\section{Methods}

We based our review on the preferred reporting items for systematic review and meta-analysis (PRISMA) guidelines, and performed both qualitative and quantitative syntheses to evaluate the treatment outcomes.

\section{Research question}

What are the treatment outcomes of SRP with and without adjunct subgingival CHX chip for managing periodontal pockets in patients with chronic periodontitis?
Patient/Population: Patients with chronic periodontitis and periodontal pockets $>4 \mathrm{~mm}$.

Intervention: Subgingival delivery of CHX chip in addition to SRP.

Comparison: Patients treated with SRP alone.

Outcomes: Clinical and Microbiological outcomes.

\section{Search strategy}

We performed a systematic digitalized search in electronic databases like MEDLINE (PubMed), Scopus, and CENT RAL (the Cochrane Central Register of Controlled Trials) using relevant keywords and strategically employed terms like 'AND', 'OR', and 'NOT'.

The strategy employed for the electronic search was as follows: "(chlorhexidine chip, periocol, periochip, OR "chlorhexidine", controlled release devices, subgingival delivery) or ("biguanides" AND "non-surgical periodontal therapy" OR "periodontal pockets", "chronic periodontitis", or periodon" OR "periodontal disease/therapy")".

We also carried out a manual search in recent issues of dental journals: Clinical Oral Investigations, European Journal of Oral Sciences, Journal of Periodontics and Restorative Dentistry, Journal of Clinical Periodontology, Journal of Dental Research, Journal of Dentistry, Journal of Periodontal Research, Journal of Periodontal and Implant Science, and Journal of Periodontology.

In addition, we screened the bibliography column of relevant clinical reports and reviews for any additional eligible clinical studies.

\section{Selection criteria}

The following criteria's were used to select potential eligible studies from the list of studies identified through our electronic and manual searches:

- Randomized clinical trials (RCTs)

- Studies employing CHX chips as an adjunct to SRP in an experimental group with comparisons to a control group with SRP alone during management of periodontal pockets $\geq 4 \mathrm{~mm}$ in patients suffering from chronic periodontitis

- Participants included in the studies were free from systemic diseases;

- Studies with participants followed for at least 1 month

- Studies published within 1st January 2006 to 1 st January 2020.

\section{Study selection}

We compiled the studies retrieved from the electronic database searches into a citation manager software (EndNote v7.0, Clarivate Analytics, USA) to remove duplicates. After that, two independent reviewers screened all the studies based on titles and abstracts. The potential 
eligible studies were subjected to full text assessment and tagged under included studies if they satisfied the selection criteria.

\section{Data extraction}

We used an Excel Spreadsheet (Microsoft, Radmond, WA, USA) to retrieve relevant detailed information from the included studies for qualitative synthesis. Two independent reviewers extracted all data from the included studies separately to eliminate errors in extraction of variables and outcomes. We contacted authors of papers missing-or with incomplete or unclear- information by telephone or email to obtain the complete details or clarify information.

\section{Outcomes}

Our outcomes included the probing pocket depth (PPD), clinical attachment level (CAL), gingival inflammation scores, and microbiological findings recorded at all follow-up periods.

\section{Data synthesis}

We analyzed the extracted data both quantitative and qualitatively, and tabulated the qualitative data and the demographics details from all the included studies. A meta-analysis was conducted when at least two studies assessed the same clinical outcome at comparable follow-up periods. Continuous data was pooled using the mean differences (MD) with 95\% confidence intervals (CI). The statistical analysis units of measurement for each outcome were tooth sites, not single patients. We used the Review Manager 5.3 software (RevMan 5.3, Version 5.3.5 Copenhagen: The Nordic Cochrane Centre, The Cochrane Collaboration, 2014.) for the meta-analysis according to the fixed or random effects models, as appropriate. We used a fixed effects meta-

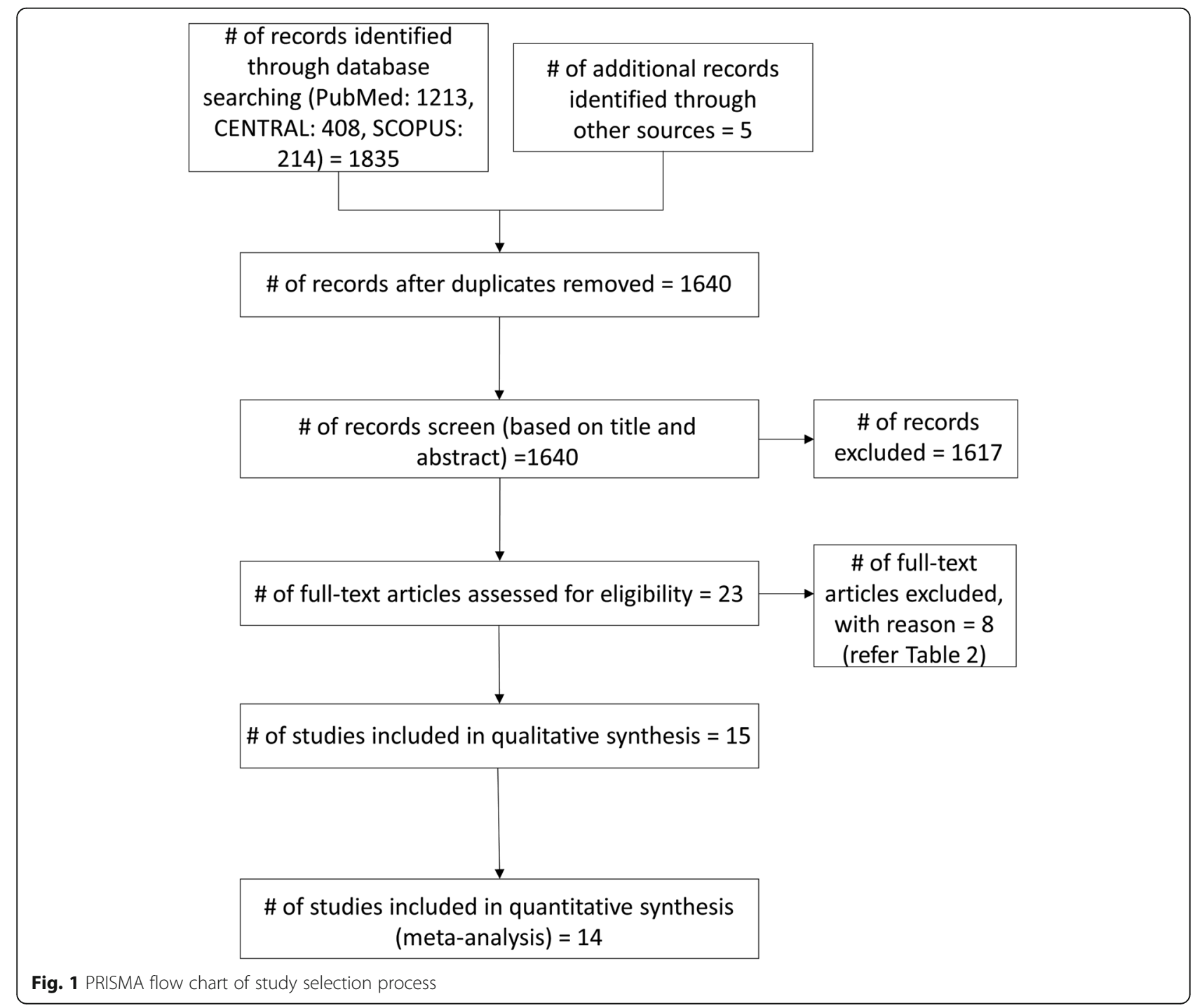


Table 1 General Characteristics of studies included

\begin{tabular}{|c|c|c|c|c|c|c|c|c|c|}
\hline Study & $\begin{array}{l}\text { Author \& } \\
\text { year }\end{array}$ & $\begin{array}{l}\text { Study } \\
\text { design }\end{array}$ & $\begin{array}{l}\text { Age } \\
\text { range }\end{array}$ & $\begin{array}{l}\text { Gender } \\
\text { (M/F) }\end{array}$ & $\begin{array}{l}\text { Sample } \\
\text { size }\end{array}$ & Groups & $\mathrm{CHX}$ chip company/make & Outcomes & $\begin{array}{l}\text { Study } \\
\text { duration }\end{array}$ \\
\hline 1 & $\begin{array}{l}\text { Sahu et al. } \\
2019 \text { [20] }\end{array}$ & $\begin{array}{l}\mathrm{RCT} \\
(\mathrm{SM})\end{array}$ & $25-55$ & NM & $\begin{array}{l}20 \\
\text { patients } \\
\text { (40 sites) }\end{array}$ & $\begin{array}{l}\text { A. SRP alone } \\
\text { ( } 20 \text { sites) } \\
\text { B. SRP plus CHX } \\
\text { chip ( } 20 \text { sites) }\end{array}$ & $\begin{array}{l}\text { PERIOCOL-CG } \\
\text { ( } 2.5 \text { mg CHX from a } 20 \% \mathrm{CHX} \\
\text { solution in fish collagen } \\
\text { membrane) }\end{array}$ & $\mathrm{PI}, \mathrm{Gl}, \mathrm{SBI}, \mathrm{PPD}, \mathrm{RAL}$ & $\begin{array}{l}3 \text { months } \\
(0,1,3)\end{array}$ \\
\hline 2 & $\begin{array}{l}\text { Singh et al. } \\
2018 \text { [21] }\end{array}$ & $\begin{array}{l}\mathrm{RCT} \\
(\mathrm{SM})\end{array}$ & $35-55$ & $15 / 5$ & $\begin{array}{l}20 \\
\text { patients } \\
\text { (40 sites) }\end{array}$ & $\begin{array}{l}\text { A. SRP alone } \\
\text { ( } 20 \text { sites) } \\
\text { B. SRP plus CHX } \\
\text { chip ( } 20 \text { sites) }\end{array}$ & NM & $\begin{array}{l}\text { PI, m-BI, PPD, CAL, } \\
\text { BANA }\end{array}$ & $\begin{array}{l}3 \text { months } \\
(0,1,3)\end{array}$ \\
\hline 3 & $\begin{array}{l}\text { Divya et al. } \\
2018 \text { [22] }\end{array}$ & $\mathrm{RCT}(\mathrm{P})$ & NM & NM & 122 sites & $\begin{array}{l}\text { A. SRP alone } \\
\text { (61 sites) } \\
\text { B. SRP plus CHX } \\
\text { chip (61 sites) }\end{array}$ & $\begin{array}{l}\text { PERIOCOL-CG } \\
(2.5 \mathrm{mg} \text { CHX from a } 20 \% \mathrm{CHX} \\
\text { solution in fish collagen } \\
\text { membrane) }\end{array}$ & $\mathrm{Gl}, \mathrm{PPD}, \mathrm{CAL}$ & $\begin{array}{l}9 \text { months } \\
(0,1,3,6,9)\end{array}$ \\
\hline 4 & $\begin{array}{l}\text { Singh et al. } \\
2017 \text { [23] }\end{array}$ & $\begin{array}{l}\mathrm{RCT} \\
(\mathrm{SM})\end{array}$ & $30-50$ & $22 / 18$ & $\begin{array}{l}40 \\
\text { patients } \\
\text { (120 sites) }\end{array}$ & $\begin{array}{l}\text { A. SRP alone } \\
\text { ( } 40 \text { sites) } \\
\text { B. SRP plus CHX } \\
\text { chip ( } 40 \text { sites) } \\
\text { C. SRP plus } \\
\text { Turmeric Chip } \\
\text { (40 sites) }\end{array}$ & $\begin{array}{l}\text { PERIOCOL-CGTM } \\
(2.5 \mathrm{mg} \text { CHX from a } 20 \% \mathrm{CHX} \\
\text { solution in fish collagen } \\
\text { membrane) }\end{array}$ & $\mathrm{PI}, \mathrm{Gl}, \mathrm{PPD}, \mathrm{RAL}$ & $\begin{array}{l}3 \text { months } \\
(0,1,3)\end{array}$ \\
\hline 5 & $\begin{array}{l}\text { Lecic et al. } \\
2016[24]\end{array}$ & $\begin{array}{l}\mathrm{RCT} \\
(\mathrm{SM})\end{array}$ & $21-52$ & $8 / 7$ & $\begin{array}{l}15 \\
\text { patients } \\
\text { (120 sites) }\end{array}$ & $\begin{array}{l}\text { A.SRP alone ( } 60 \\
\text { sites) } \\
\text { B. SRP pus CHX } \\
\text { gel ( } 20 \text { sites) } \\
\text { C.SRP plus CHX } \\
\text { irrigation ( } 20 \\
\text { sites) } \\
\text { D. SRP plus } \\
\text { CHX chip ( } 20 \\
\text { sites) }\end{array}$ & $\begin{array}{l}\text { Perio Chip }{ }^{\oplus} \text {, Perioproducts, } \\
\text { Jerusalem, Israel }\end{array}$ & $\mathrm{Pl}, \mathrm{BOP}, \mathrm{PPD}, \mathrm{CAL}$ & $\begin{array}{l}3 \text { months } \\
(0,1,3)\end{array}$ \\
\hline 6 & $\begin{array}{l}\text { John et al., } \\
2015 \text { [25] }\end{array}$ & $\begin{array}{l}\mathrm{RCT} \\
\text { (SM) }\end{array}$ & $35-56$ & $11 / 9$ & $\begin{array}{l}20 \\
\text { patients } \\
\text { (40 sites) }\end{array}$ & $\begin{array}{l}\text { A. SRP alone } \\
\text { ( } 20 \text { sites) } \\
\text { B. SRP plus CHX } \\
\text { chip ( } 20 \text { sites) }\end{array}$ & $\begin{array}{l}2.5 \mathrm{mg} \mathrm{CHX} \text { from a } 20 \% \mathrm{CHX} \\
\text { solution in fish collagen } \\
\text { membrane }\end{array}$ & $\mathrm{Pl}, \mathrm{Gl}, \mathrm{PPD}, \mathrm{CAL}$ & $\begin{array}{l}3 \text { months } \\
(0,11 \text { days, } \\
11 \text { weeks })\end{array}$ \\
\hline 7 & $\begin{array}{l}\text { Pattnaik } \\
\text { et al., } 2015 \\
\text { [26] }\end{array}$ & $\begin{array}{l}\mathrm{RCT} \\
(\mathrm{SM})\end{array}$ & $29-54$ & $9 / 11$ & $\begin{array}{l}20 \\
\text { patients } \\
\text { (40 sites) }\end{array}$ & $\begin{array}{l}\text { A. SRP alone } \\
\text { (10 sites) } \\
\text { B. SRP plus CHX } \\
\text { chip (10 sites) }\end{array}$ & $\begin{array}{l}\text { PERIOCOL-CG } \\
(2.5 \mathrm{mg} \text { CHX from a } 20 \% \mathrm{CHX} \\
\text { solution in fish collagen } \\
\text { membrane) }\end{array}$ & $\begin{array}{l}\text { PD, CAL, Gl, Bacterial } \\
\text { Count }\end{array}$ & $\begin{array}{l}3 \text { months } \\
(0,1,3)\end{array}$ \\
\hline 8 & $\begin{array}{l}\text { Kumar et al., } \\
2014 \text { [27] }\end{array}$ & $\mathrm{RCT}(\mathrm{P})$ & $20-65$ & $15 / 15$ & $\begin{array}{l}30 \\
\text { patients } \\
\text { (30 sites) }\end{array}$ & $\begin{array}{l}\text { A. SRP alone } \\
\text { (10 sites) } \\
\text { B. SRP plus CHX } \\
\text { chip (10 sites) } \\
\text { C. CHX chip } \\
\text { alone (10 sites) }\end{array}$ & $\begin{array}{l}\text { PERIOCOL-CG } \\
(2.5 \mathrm{mg} \text { CHX from a } 20 \% \mathrm{CHX} \\
\text { solution in fish collagen } \\
\text { membrane) }\end{array}$ & Gl, PPD, CAL, BANA & $0,1,3 \mathrm{~m}$ \\
\hline 9 & $\begin{array}{l}\text { Medaiah } \\
\text { et al. } 2014 \\
{[28]}\end{array}$ & $\mathrm{RCT}(\mathrm{P})$ & $35-55$ & $6 / 9$ & $\begin{array}{l}15 \\
\text { patients } \\
\text { (45 sites) }\end{array}$ & $\begin{array}{l}\text { A. SRP alone } \\
\text { (15 sites) } \\
\text { B. SRP plus CHX } \\
\text { chip (15 sites) } \\
\text { C. CHX chip } \\
\text { alone (15 sites) }\end{array}$ & $\begin{array}{l}\text { Perio Chip }{ }^{\oplus} \text {, Perioproducts, } \\
\text { Jerusalem, Israel }\end{array}$ & $\mathrm{Pl}, \mathrm{Gl}, \mathrm{BOP}, \mathrm{PD}, \mathrm{CAL}$ & $\begin{array}{l}3 \text { months } \\
(0,1,3)\end{array}$ \\
\hline 10 & $\begin{array}{l}\text { Pai et al. } \\
2013 \text { [17] }\end{array}$ & $\mathrm{RCT}(\mathrm{P})$ & $35-55$ & $7 / 8$ & $\begin{array}{l}15 \\
\text { patients } \\
\text { (45 sites) }\end{array}$ & $\begin{array}{l}\text { A. SRP alone } \\
\text { (15 sites) } \\
\text { B. SRP plus CHX } \\
\text { Varnish ( } 15 \\
\text { sites) } \\
\text { C. SRP plus } \\
\text { CHX chip (15 } \\
\text { sites) }\end{array}$ & NM & $\mathrm{PI}, \mathrm{BOP}, \mathrm{SBI}, \mathrm{PPD}, \mathrm{CAL}$ & $\begin{array}{l}3 \text { months } \\
(0,1,3)\end{array}$ \\
\hline 11 & $\begin{array}{l}\text { Puri et al. } \\
2013 \text { [29] }\end{array}$ & $\begin{array}{l}\mathrm{RCT} \\
(\mathrm{SM})\end{array}$ & $30-50$ & $8 / 7$ & $\begin{array}{l}15 \\
\text { patients } \\
\text { (30 sites) }\end{array}$ & $\begin{array}{l}\text { A. SRP alone } \\
\text { (15 sites) } \\
\text { B. SRP plus CHX } \\
\text { chip ( } 15 \text { sites) }\end{array}$ & $\begin{array}{l}\text { Perio Chip }{ }^{\oplus} \text {, Perioproducts, } \\
\text { Jerusalem, Israel }\end{array}$ & $\mathrm{Gl}, \mathrm{PI}, \mathrm{PPD}, \mathrm{CAL}, \mathrm{TCC}$ & $\begin{array}{l}3 \text { months } \\
(0,1,3)\end{array}$ \\
\hline
\end{tabular}


Table 1 General Characteristics of studies included (Continued)

\begin{tabular}{|c|c|c|c|c|c|c|c|c|c|}
\hline Study & $\begin{array}{l}\text { Author \& } \\
\text { year }\end{array}$ & $\begin{array}{l}\text { Study } \\
\text { design }\end{array}$ & $\begin{array}{l}\text { Age } \\
\text { range }\end{array}$ & $\begin{array}{l}\text { Gender } \\
\text { (M/F) }\end{array}$ & $\begin{array}{l}\text { Sample } \\
\text { size }\end{array}$ & Groups & CHX chip company/make & Outcomes & $\begin{array}{l}\text { Study } \\
\text { duration }\end{array}$ \\
\hline 12 & $\begin{array}{l}\text { Grover et al., } \\
2011[30]\end{array}$ & $\mathrm{RCT}(\mathrm{P})$ & $30-65$ & $28 / 12$ & $\begin{array}{l}40 \\
\text { patients } \\
\text { (40 sites) }\end{array}$ & $\begin{array}{l}\text { A. SRP alone } \\
\text { ( } 20 \text { sites) } \\
\text { B. SRP plus CHX } \\
\text { chip ( } 20 \text { sites) }\end{array}$ & $\begin{array}{l}\text { PERIOCOL-CG }{ }^{\mathrm{TM}} \\
\text { ( } 2.5 \mathrm{mg} \mathrm{CHX} \text { from a } 20 \% \mathrm{CHX} \\
\text { solution in fish collagen } \\
\text { membrane) }\end{array}$ & $\begin{array}{l}\text { PPD, CAL, BI and } \\
\text { Radiological parameters } \\
\text { (bone gain) }\end{array}$ & $\begin{array}{l}3 \text { months } \\
(7 \text { th day, 1, } \\
2,3)\end{array}$ \\
\hline 13 & $\begin{array}{l}\text { Sakellari } \\
\text { et al., } 2010 \\
\text { [31] }\end{array}$ & $\mathrm{RCT}(\mathrm{P})$ & $35-75$ & $25 / 25$ & $\begin{array}{l}50 \\
\text { patients } \\
\text { (50 sites) }\end{array}$ & $\begin{array}{l}\text { A. SRP alone } \\
\text { ( } 25 \text { sites) } \\
\text { B. SRP plus CHX } \\
\text { chip ( } 25 \text { sites) }\end{array}$ & $\begin{array}{l}\text { Perio Chip }{ }^{\oplus} \text {, Perioproducts, } \\
\text { Jerusalem, Israel }\end{array}$ & $\begin{array}{l}\text { PPD, CAL, BOP, Bacterial } \\
\text { Count }\end{array}$ & $\begin{array}{l}6 \text { months } \\
(0,3 \text { weeks, } \\
3,6)\end{array}$ \\
\hline 14 & $\begin{array}{l}\text { Paolantonio } \\
\text { et al., } 2008 \\
\text { [32] }\end{array}$ & $\begin{array}{l}\mathrm{RCT} \\
(\mathrm{SM})\end{array}$ & $33-65$ & $34 / 82$ & $\begin{array}{l}116 \\
\text { patients } \\
\text { (232 sites) }\end{array}$ & $\begin{array}{l}\text { A. SRP alone } \\
\text { (116 sites) } \\
\text { B. SRP plus CHX } \\
\text { chip (116 sites) }\end{array}$ & $\begin{array}{l}\text { Perio Chip }{ }^{\oplus} \text {, Perioproducts, } \\
\text { Jerusalem, Israel }\end{array}$ & $\begin{array}{l}\text { PPD, RAL, BOP, Bacterial } \\
\text { Count }\end{array}$ & $\begin{array}{l}6 \text { months } \\
(0,3,6)\end{array}$ \\
\hline 15 & $\begin{array}{l}\text { Paolantonio } \\
\text { et al., } 2008 \\
\text { [33] }\end{array}$ & $\begin{array}{l}\mathrm{RCT} \\
(\mathrm{SM})\end{array}$ & $31-63$ & $33 / 49$ & $\begin{array}{l}82 \\
\text { patients } \\
\text { (164 sites) }\end{array}$ & $\begin{array}{l}\text { A. SRP alone } \\
\text { ( } 82 \text { sites) } \\
\text { B. SRP plus CHX } \\
\text { chip ( } 82 \text { sites) }\end{array}$ & $\begin{array}{l}\text { Perio Chip }{ }^{\oplus} \text {, Perioproducts, } \\
\text { Jerusalem, Israel }\end{array}$ & $\begin{array}{l}\text { PPD, RAL, BOP, GCF- } \\
\text { ALP }\end{array}$ & $\begin{array}{l}6 \text { months } \\
(0,3,6)\end{array}$ \\
\hline
\end{tabular}

Legend: $R C T$ Randomized controlled trial, SM Split-mouth, $P$ Parallel, SRP Scaling and root planing, CHX Chlorhexidine, $P I$ Plaque index, GI Gingival index, BI Bleeding index, SBI Sulcus bleeding index, PPD Probing pocket depth, CAL Clinical attachment level, RAL Relative attachment level, $B O P$ Bleeding on probing, TCC Total colony count, BANA N-benzoyl D, L-arginine-2-naphthylamide test kit, GCF Gingival crevicular fluid, ALP Alkaline phosphatase

analysis when the heterogeneity was small $\left(I^{2}<60 \%\right.$, $P>0.05)$, and a random-effects model analysis when the heterogeneity was large $\left(I^{2}>60 \%, P<0.05\right)$.

\section{Risk of bias assessment}

The risk of bias assessment was carried out according to guidelines in the Cochrane Handbook of Systematic Reviews of Interventions using Revman 5.3 software. We carefully assigned bias pertaining to randomization process and allocation concealment, blinding of participants, personnel or assessor, and any incomplete or selective outcome data reporting to assess risks of bias for all the included studies. Two reviewers independently judged the assessments and consulted a third reviewer in cases of discrepancies or doubt to arrive at a consensus. The individual assessments of bias were judged as low in case of valid information, unclear in case of lack of clarity, and high in case of missing or invalid information. The reviewers further graded the studies based on their bias assessment scores (low risk studies had low scores on all assessments, medium risk studies had one or more unclear bias assessment scores; and high risk studies had high scores).

\section{Results}

The systematic selection process of eligible studies is provided in the PRISMA flow chart (Fig. 1). A total of 1640 unique records were identified of which 15 studies were included. Details of included studies are presented in Table 1. Table 2 lists the reasons for exclusion of studies after full text assessments.

Out of 15 included reports, nine were split mouth studies, and the other six were of parallel design. The included studies involved a total of 620 patients with 998 treatment sites randomly divided into SRP alone (509 sites) and SRP plus CHX chip (489 sites) groups. The sample size per arm varied from a minimum of 30 sites to a maximum of 232 sites. The CHX chips used in the studies had $2.5 \mathrm{mg}$ of $\mathrm{CHX}$ (20\% CHX embedded in a collagen matrix) under the brand name of PERIOCOL CG (Eucare Pharmaceuticals, India) or PERIOCHIP (Perioproducts, Jerusalem, Israel). The follow-up duration among the studies varied from a minimum of 1 month to a maximum of 9 months, with maximum outcomes recorded at the end of 1 and 3 months.

We found eight studies [20, 21, 27-30, 32, 33] with moderate and four $[17,24-26]$ with low risk of bias. Three of the trials $[22,23,31]$ had high risks of bias due to lack of information or inappropriateness regarding allocation concealment and blinding of participants, personnel, or outcome assessors (Fig. 2).

Table 2 Reasons for excluding studies

\begin{tabular}{|c|c|c|}
\hline Study & Author \& year & Reason for exclusion \\
\hline 1 & $\begin{array}{l}\text { Konugati et al. } 2016 \\
\text { [34] }\end{array}$ & Positive control (Flurbiprofen) \\
\hline 2 & Jhinger et al. 2015 [35] & Not a randomized clinical trial \\
\hline 3 & Singh et al. 2014 [36] & $\begin{array}{l}\text { Low quality RCT (Randomization not } \\
\text { clear) }\end{array}$ \\
\hline 4 & $\begin{array}{l}\text { Kondreddy et al. } 2012 \\
\text { [37] }\end{array}$ & Comparative study \\
\hline 5 & Matchei et al. 2011 [38] & Positive control (Flurbiprofen) \\
\hline 6 & $\begin{array}{l}\text { Gonzales et al. } 2011 \\
\text { [39] }\end{array}$ & Use of placebo as control \\
\hline 7 & $\begin{array}{l}\text { Tara Paul et al. } 2010 \\
{[40]}\end{array}$ & Comparison with surgical treatment \\
\hline 8 & Kasaj et al. 2007 [41] & Supportive periodontal therapy \\
\hline
\end{tabular}




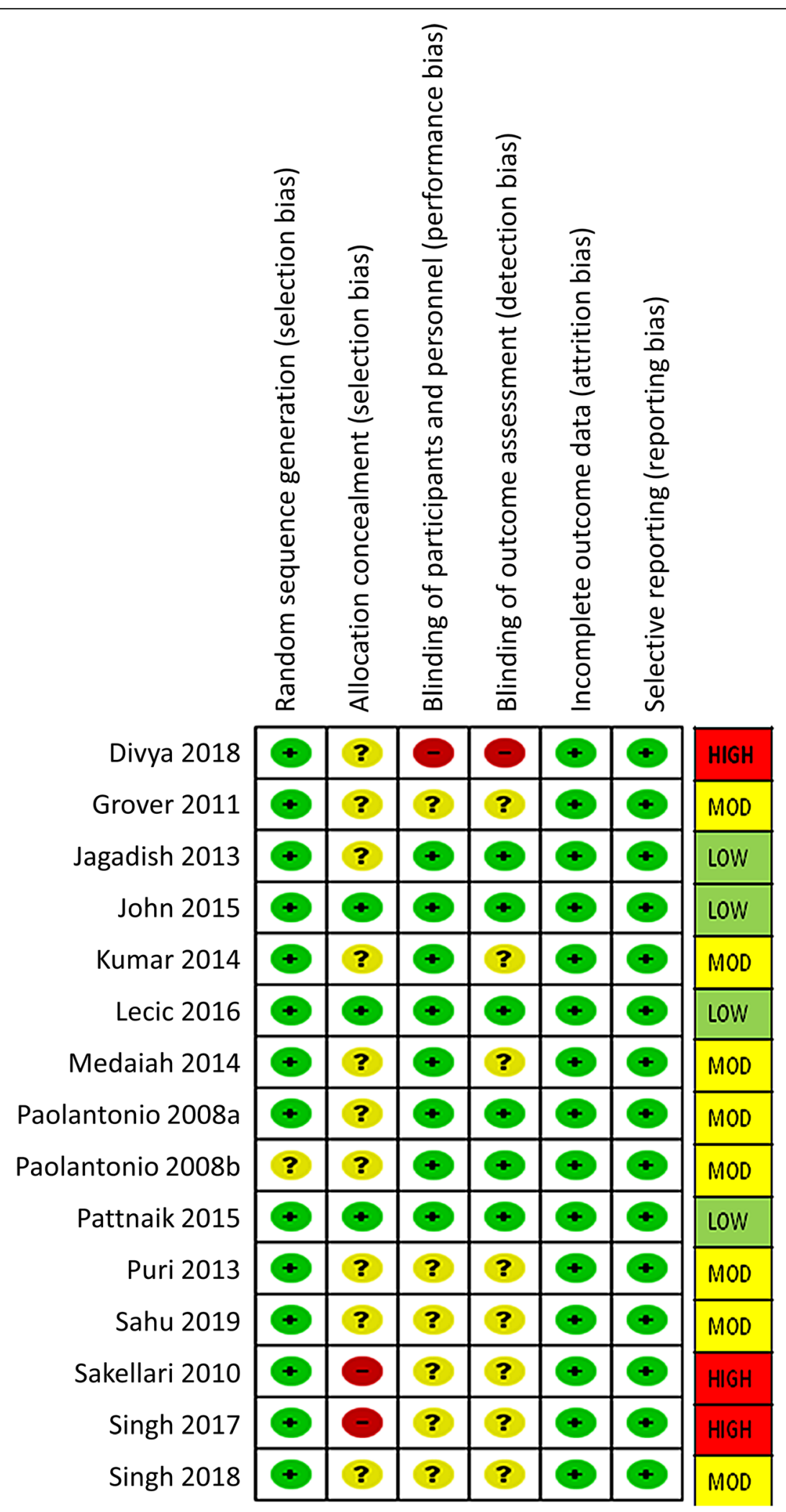

Fig. 2 Risk of Bias (RoB) assessment for included studies 
We carried out quantitative analyses to compare outcomes between the groups based on gain in CAL, reduction in PPD, and improvement in gingival inflammation scores. We used data from 14 studies for our meta-analysis plots. We plotted MD between the groups of the 14 included studies into forest plots at all follow-ups. We also performed subgroup analyses according to their study design.

\section{PPD reductions}

\section{At 1-month follow-up}

We combined data from 10 studies [17, 21-24, 26-30] to compare the reduction in PPD between the groups at the 1 month follow-ups. Figure 3 shows the forest plot for the mean differences in PPD reduction PPD at 1month between groups, which suggests the sites treated with SRP and CHX chip had better outcomes than the sites treated with SRP alone (MD, 0.63; 95\% CI 0.44$0.82 ; p<0.001)$.

\section{At 3-month follow-up}

We combined data from 13 studies [17, 21-32] to compare the PPD reduction between the groups at the 3 month follow-ups. Figure 4 shows the forest plot with mean differences in PPD reduction between groups and suggests that the sites treated with SRP and CHX chip had a better response than those treated with SRP alone (MD, 0.69; 95\% CI, 0.43-0.95; $p<0.001$ ).

\section{At 6-month follow-up}

We combined data from only 4 studies [22, 31-33] to compare the PPD reduction between the groups at the 6-month follow-ups. Figure 5 shows the forest plot with mean differences in PPD reduction between groups, and suggests the sites treated with SRP and CHX chip had a better response than those treated with SRP alone (MD, 0.75; 95\% CI, 0.72-0.77; $p<0.001$ ).

\section{CAL gains}

At 1-month follow-up

We combined data from 10 studies [17, 21-24, 26-30] to compare CAL gains between groups at the 1-month follow-ups. Figure 6 shows the forest plot with mean differences in CAL gains between groups, suggesting that the sites treated with SRP and CHX chip had a better

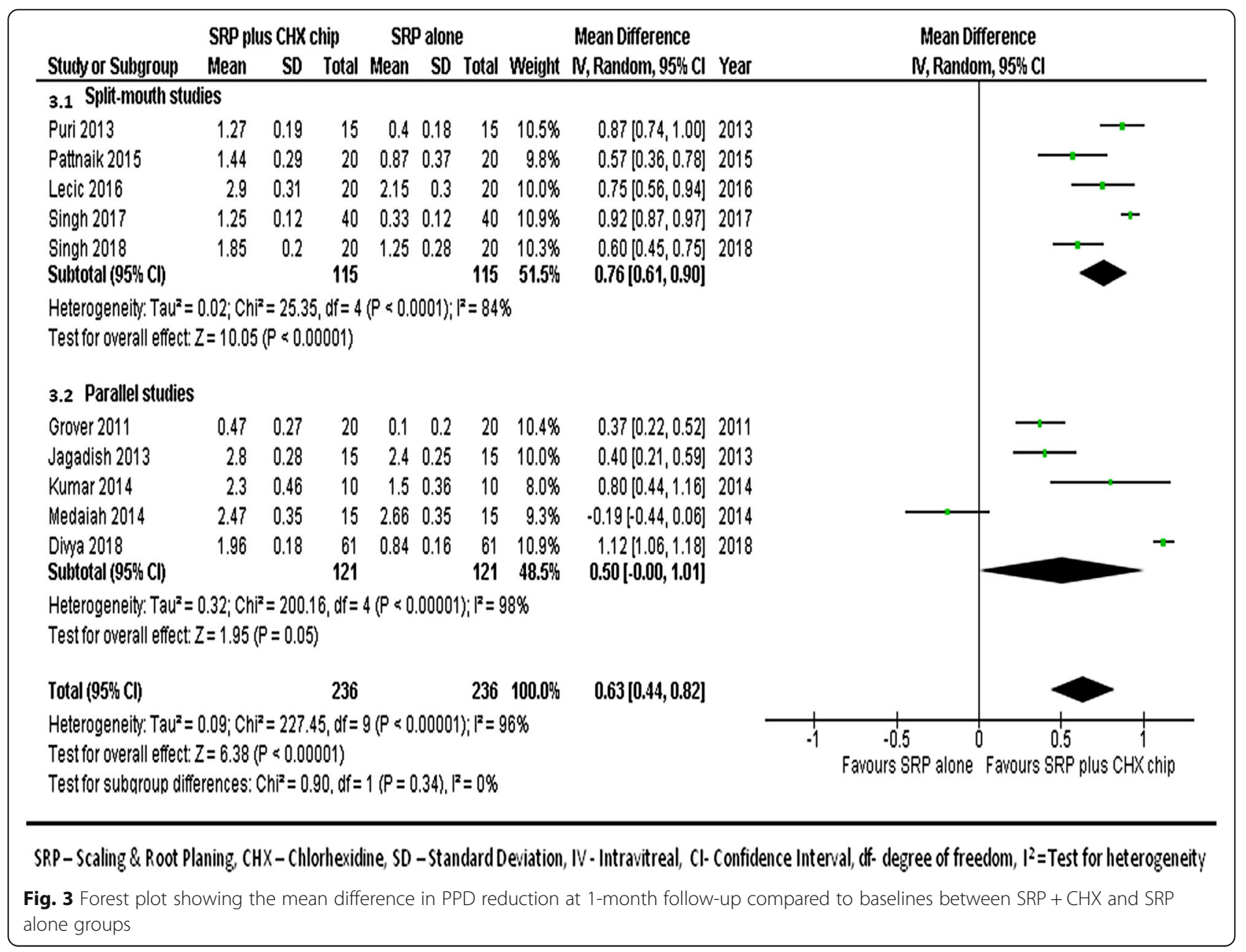




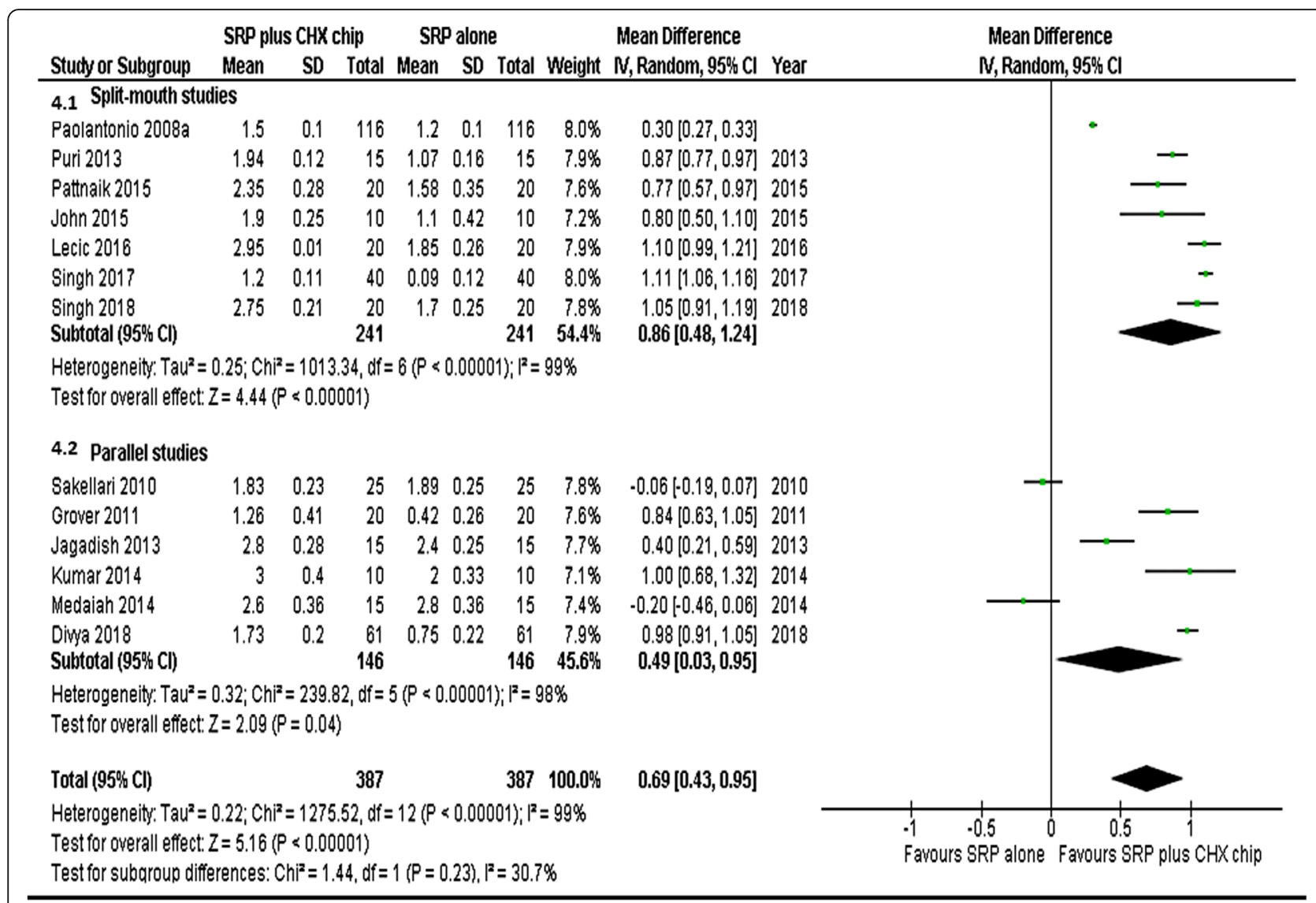

SRP - Scaling \& Root Planing, CHX - Chlorhexidine, SD - Standard Deviation, IV - Intravitreal, CI- Confidence Interval, df- degree of freedom, I²=Test for heterogeneity

Fig. 4 Forest plot showing the mean difference in PPD reductions at 3-month follow-up compared to baselines between SRP + CHX and SRP alone groups

response than those treated with SRP alone (MD, 0.54; 95\% CI, 0.26-0.81; $p<0.001)$.

\section{At 3-month follow-up}

The combined data from 13 studies [17, 21-32] to compare the CAL gains between groups at the 3 month follow-ups shows the forest plot with mean differences in CAL gains between groups (Fig. 7), suggesting that sites treated with SRP and CHX chip had a better response than those treated with SRP alone (MD, 0.64; 95\% CI, 0.36-0.92; $p<0.001$ ).

\section{At 6-month follow-up}

We combined data from 4 studies [22, 31-33] to compare the CAL gains between groups at the 6 month follow-ups. Figure 8 shows the forest plot with mean

\begin{tabular}{|c|c|c|c|c|c|c|c|c|c|c|c|c|}
\hline Stucty or Subgroup & \multicolumn{3}{|c|}{ SRP plus $\mathrm{CHX}$ chip } & \multicolumn{3}{|c|}{ SRP alone } & \multicolumn{2}{|r|}{ Mean Difference } & \multicolumn{4}{|c|}{$\begin{array}{l}\text { Mean Difference } \\
\text { N, Fixed, } 95 \% \mathrm{Cl}\end{array}$} \\
\hline Diwa 2018 & 2.4 & 0.21 & 61 & 0.88 & 0.22 & 61 & $9.7 \%$ & $1.52[1.44,1.60]$ & & & & $\rightarrow$ \\
\hline Paolantonio 2008a & 1.5 & 0.1 & 116 & 0.8 & 0.1 & 116 & $84.9 \%$ & $0.70[0.67,0.73]$ & & & & \\
\hline Paolantonio 2008b & 2.7 & 0.4 & 82 & 1.9 & 0.7 & 82 & $1.8 \%$ & $0.80[0.63,0.97]$ & & & & \\
\hline Sakellari 2010 & 1.79 & 0.24 & 25 & 2.05 & 0.21 & 25 & $3.6 \%$ & $-0.26[-0.39,-0.13]$ & & - & & \\
\hline & & & 284 & & & 284 & $100.0 \%$ & $0.75[0.72,0.77]$ & & & & 1 \\
\hline \multicolumn{7}{|c|}{$\begin{array}{l}\text { Heterogeneity: } C h i^{2}=656.49, d f=3(P<0.00001) ; I^{2}=100 \% \\
\text { Test for overall effect: } Z=61.70(P<0.00001)\end{array}$} & & & -2 & $\begin{array}{c}-1 \\
\text { Favours SRP alone }\end{array}$ & Favours & $\begin{array}{cc}1 & 2 \\
\text { SRP plus } \mathrm{CH} X \mathrm{Chip}\end{array}$ \\
\hline
\end{tabular}

SRP - Scaling \& Root Planing, CHX - Chlorhexidine, SD - Standard Deviation, IV - Intravitreal, CI- Confidence Interval, df- degree of freedom, $I^{2}=$ Test for heterogeneity

Fig. 5 Forest plot showing the mean difference in PPD reductions at 6-month follow-up compared to baselines between SRP + CHX and SRP alone groups 


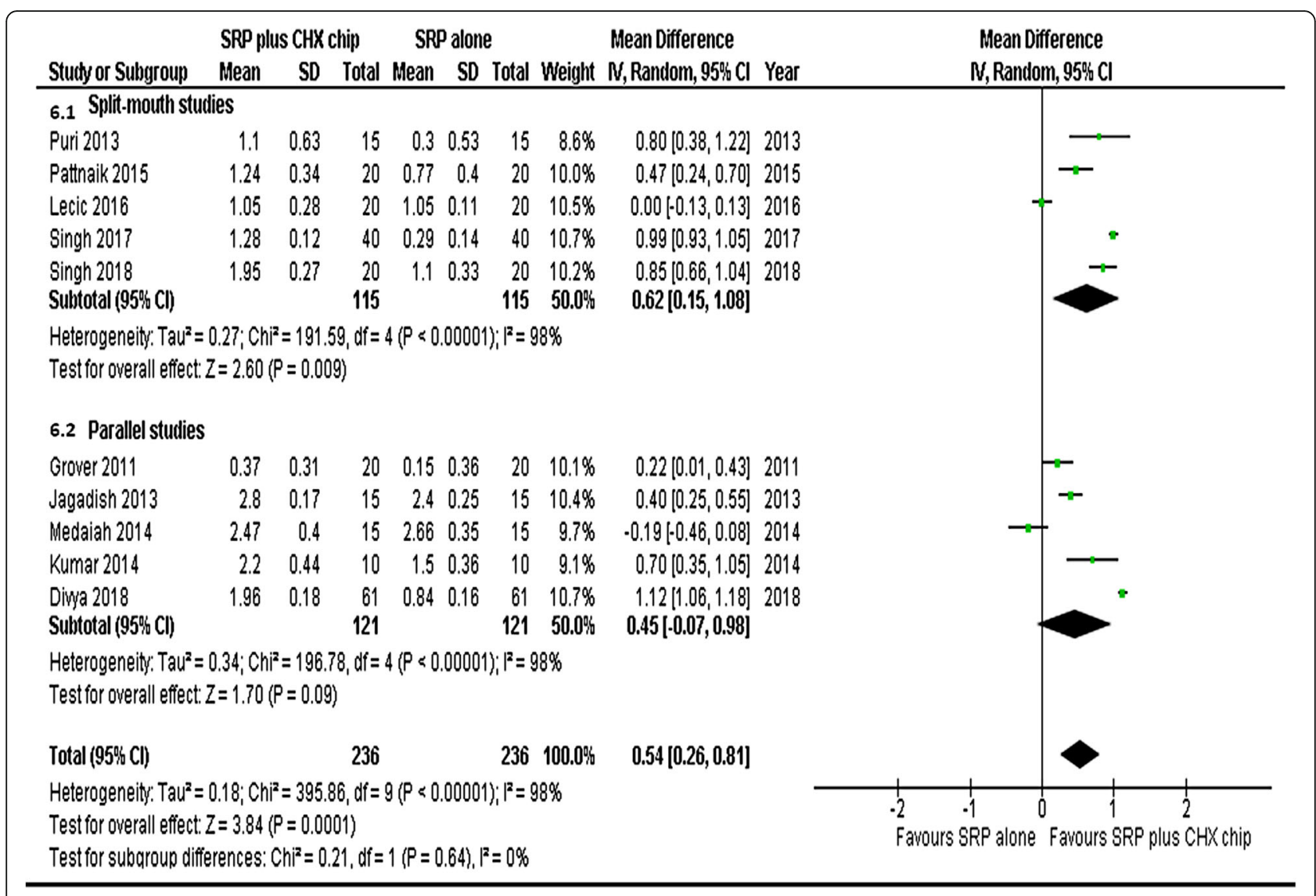

SRP - Scaling \& Root Planing, CHX - Chlorhexidine, SD -Standard Deviation, IV - Intravitreal, CI-Confidence Interval, dif- degree of freedom, $I^{2}=$ Test for heterogeneity

Fig. 6 Forest plot showing the mean difference in clinical attachment gains at 1-month follow-up compared to baselines between SRP + CHX and SRP alone groups

differences in CAL gains between groups, suggesting that the sites treated with SRP and CHX chip had a better response than those treated with SRP alone (MD, 0.68 ; 95\% CI, 0.65-0.70; $p<0.001$ ).

\section{Gingival inflammation improvement At 1-month follow-up}

We combined data from 5 studies [22, 23, 26, 27, 29] to compare gingival inflammation score improvements between groups at 1-month follow-ups. Figure 9 shows the forest plot with mean differences in GI score improvements between groups, suggesting that sites treated with SRP and CHX chip had a better response than those treated with SRP alone (MD, 0.29; 95\% CI, 0.06-0.52; $p<0.001$ ).

\section{At 3-month follow-up}

We combined data from 6 studies [22, 23, 25-27, 29] to compare the GI score improvements between groups at 3-month follow-up. Figure 10 shows the forest plot with mean differences in GI score improvements between groups, suggesting that the sites treated with SRP and CHX chip had a better response than those treated with SRP alone (MD, 0.32; 95\% CI, 0.15-0.48; $\mathrm{p}<0.001$ ).

\section{Microbiological findings}

We did not attempt to produce a forest plot to compare microbiological outcomes (such as total colony counts, reduction in periodontal pathogens, or color change in BANA test kit) because of unavailability of more than 2 studies with similar outcome variables.

However, we produced a qualitative synthesis of the included reports evaluating microbiological outcomes. Two studies $[21,27]$ evaluating \%BANA positive sites showed significant reductions in the amount of sites positive for Treponema denticola, Tannerella forsythia, and Porphyromonas gingivalis when treated with SRP plus CHX chip. We also found similar results in other 4 studies evaluating mean periodontal pathogens reductions through quantitative-PCR that showed better outcomes in sites treated with SRP and CHX chip than in those treated with SRP alone [23, 26, 29, 32]. 


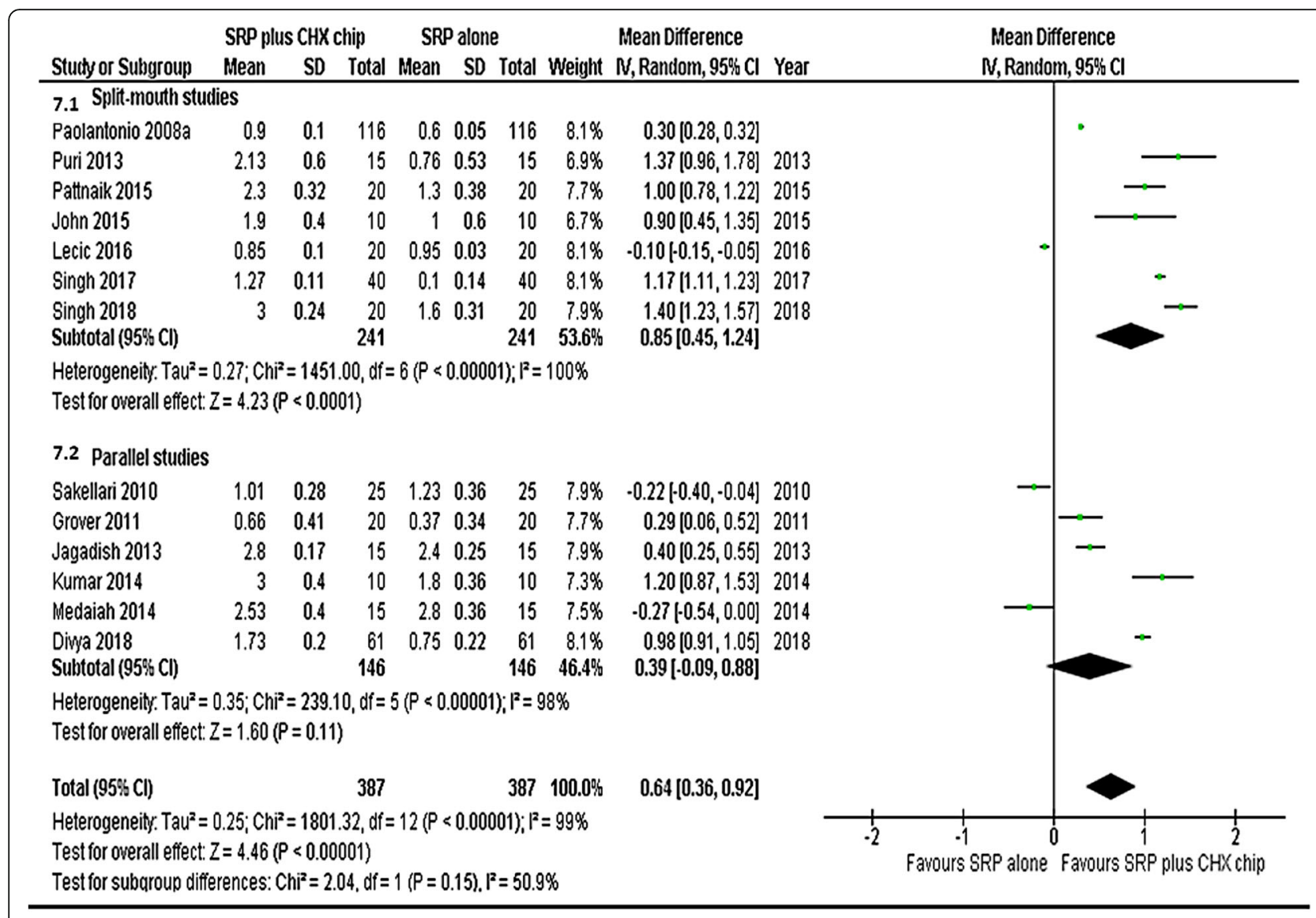

SRP - Scaling \& Root Planing, CHX - Chlorhexidine, SD - Standard Deviation, IV - Intravitreal, CI- Confidence Interval, df- degree of freedom, I²=Test for heterogeneity

Fig. 7 Forest plot showing the mean difference in clinical attachment gains at 3-month follow-up compared to baselines between SRP + CHX and SRP alone groups

\section{Discussion}

This systematic review and meta-analysis evaluated the effect of the CHX chip as an adjunct treatment to SRP for the management of periodontal pockets in patients with chronic periodontitis. The RCTs included in this meta-analysis were mostly of low and moderate risks of bias. However, three trials had high risks of bias due to lack of allocation concealment or inadequacy in blinding of participants, personnel, or outcome assessors.

CHX has shown promising and effective clinical benefits when used as a mouthwash [15]. However, its effectiveness in deep subgingival areas and inaccessible anatomical contours has remained unclear. Consequently, CHX chips have been devised which allow for

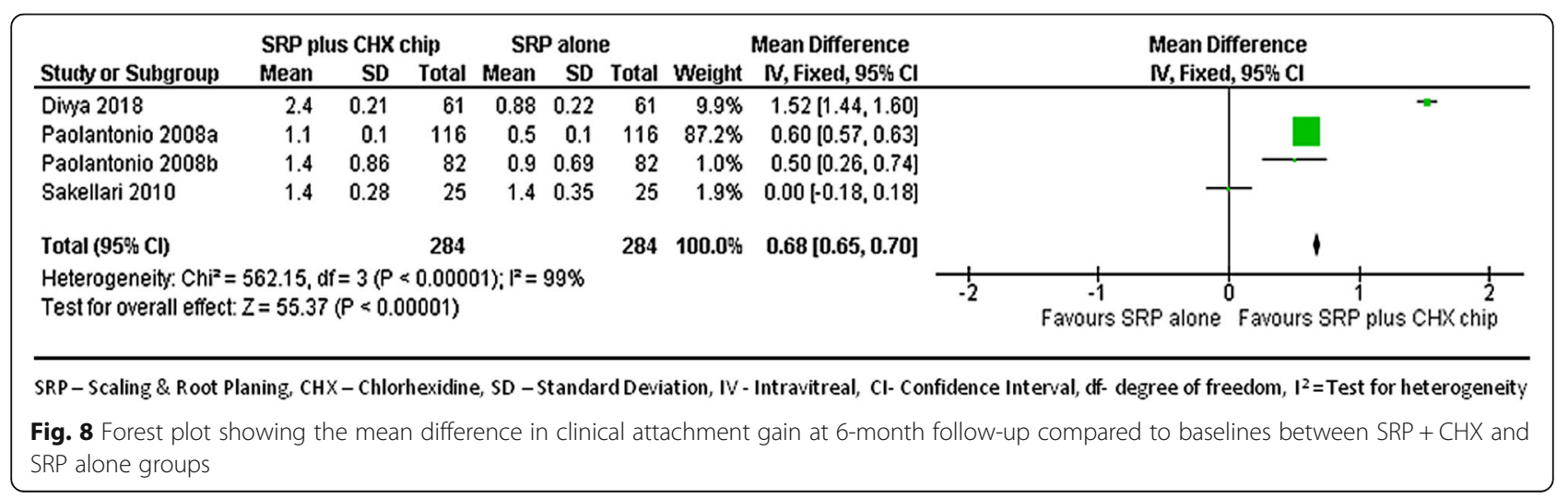




\begin{tabular}{|c|c|c|c|c|c|c|c|c|c|c|c|c|c|}
\hline Stucty or Subgroup & \multicolumn{3}{|c|}{ SRP plus CHX chip } & \multicolumn{3}{|c|}{ SRP alone } & Weight & $\begin{array}{l}\text { Mean Difference } \\
\mathrm{N}, \mathrm{Random}, 95 \% \mathrm{Cl}\end{array}$ & Year & \multicolumn{4}{|c|}{$\begin{array}{c}\text { Mean Difference } \\
\mathrm{N}, \text { Random, } 95 \% \mathrm{CI}\end{array}$} \\
\hline Puri 2013 & 0.43 & 0.07 & 15 & 0.19 & 0.06 & 15 & $20.3 \%$ & $0.24[0.19,0.29]$ & 2013 & & & $=$ & \\
\hline Kumar 2014 & 1.59 & 0.14 & 10 & 1.17 & 0.09 & 10 & $19.7 \%$ & $0.42[0.32,0.52]$ & 2014 & & & & - \\
\hline Pattnaik 2015 & 0.81 & 0.21 & 20 & 0.74 & 0.22 & 20 & $19.2 \%$ & $0.07[-0.06,0.20]$ & 2015 & & & - & \\
\hline Singh 2017 & 0.54 & 0.11 & 40 & 0.41 & 0.13 & 40 & $20.3 \%$ & $0.13[0.08,0.18]$ & 2017 & & & $=$ & \\
\hline Diwa 2018 & 1.43 & 0.07 & 61 & 0.84 & 0.06 & 61 & $20.5 \%$ & $0.59[0.57,0.61]$ & 2018 & & & & $=$ \\
\hline \multirow{2}{*}{\multicolumn{8}{|c|}{$\begin{array}{l}\text { Total }(95 \% \mathrm{Cl}) \quad \mathbf{1 4 6} \quad 146 \quad \mathbf{1 0 0 . 0 \%} \% \\
\text { Heterogeneity: Tau }{ }^{2}=0.07 ; \mathrm{Chi}^{2}=390.36, \mathrm{df}=4(\mathrm{P}<0.00001) ; \mathrm{F}^{2}=99 \% \\
\text { Test for overall effect: } Z=2.48(\mathrm{P}=0.01)\end{array}$}} & $0.29[0.06,0.52]$ & & & & & \\
\hline & & & & & & & & & & $\frac{1}{-1}$ & $\begin{array}{c}-0.5 \\
\text { Favours SRP alone }\end{array}$ & Favours & $\begin{array}{c}0.5 \\
\text { SRP plus } \mathrm{CH} \times \mathrm{Chi}\end{array}$ \\
\hline
\end{tabular}

SRP - Scaling \& Root Planing, CHX - Chlorhexidine, SD - Standard Deviation, IV - Intravitreal, CI- Confidence Interval, df- degree of freedom, $\mathrm{I}^{2}=$ Test for heterogeneity

Fig. 9 Forest plot showing the mean difference in gingival inflammation reduction at 1-month follow-up compared to baselines between SRP + $\mathrm{CHX}$ and SRP alone groups

ease of placement into the subgingival sites and provide sustained release of CHX over a period of time. The efficacy of CHX chips against periodontal pathogens has been a subject of research, however, the results have been conflicting $[42,43]$. An in-vitro study has shown that Porphyromonas gingivalis can inactivate the CHX molecule by releasing vesicles that surround the microorganism's capsule, thereby protecting it and also other micro-organisms from the antibacterial effects of CHX [33]. On the other hand, CHX has been reported to be a potent anti-bacterial agent that inhibits microbial proteases released from potent periodontopathogens [44]. Thus, whether the anti-microbial effect of CHX chips results in clinical benefits when placed into deep periodontal pockets needs to be thoroughly investigated.

In one of the earliest systematic reviews on the subject, Cosyn et al. in 2006 reviewed 5 RCTs studying the adjunctive use of CHX chip with SRP. However, due to the limited and conflicting data from the included studies, the authors failed to derive strong conclusions and suggested the need for more RCTs to confirm the beneficial effect of $\mathrm{CHX}$ chips over conventional nonsurgical periodontal treatment [19]. That review also concluded that SRP is a prerequisite for any chemotherapy or local drug delivery agent such as the CHX chip, limiting the beneficial effects of CHX chips used alone without root planing [19].

In the current study, we included RCTs only from 2007 to 2019 with an intention to provide a review of only the latest evidence on the topic published after the Cosyn et al. [19] review. The primary outcomes assessed in the studies of this review included PPD reduction, CAL gain, GI improvement, and bleeding on probing (BOP). The assessment of BOP is a clear indicator of pocket activity. But, as only a few studies assessed BOP with heterogenous data collection (some assessing presence of BOP alone, and others percentage of BOP sites), a meta-analysis could not be performed.

PPD is a commonly used diagnostic tool for assessing destruction of periodontal structures and PPD along with CAL are important clinical indicators for both diagnosis of periodontal disease and monitoring the of success of treatment [24]. In our analysis, we found a statistically significant difference in PPD reductions between the study groups at 1 month (MD 0.63), 3 months (MD 0.69), and 6 months (MD 0.75) with results favoring sites treated with CHX chip and SRP. The improvement in the PPD with CHX and SRP was seen in all studies except for Medaiah et al. [28] and Sakellari et al. [31]. Our meta-analysis also demonstrated significant

\begin{tabular}{|c|c|c|c|c|c|c|c|c|c|c|c|c|}
\hline Study or Subgroup & \multicolumn{3}{|c|}{ SRP plus CHX Chip } & \multicolumn{3}{|c|}{ SRP alone } & Weight & $\begin{array}{l}\text { Mean Difference } \\
\mathrm{N}, \text { Random, } 95 \% \mathrm{Cl}\end{array}$ & Year & \multicolumn{2}{|c|}{$\begin{array}{c}\text { Mean Difference } \\
N, \text { Random, } 95 \% \mathrm{Cl}\end{array}$} & \\
\hline Puri 2013 & 0.8 & 0.05 & 15 & 0.34 & 0.07 & 15 & $17.4 \%$ & $0.46[0.42,0.50]$ & 2013 & & & $=$ \\
\hline Kumar 2014 & 1.72 & 0.07 & 10 & 1.57 & 0.09 & 10 & $17.1 \%$ & $0.15[0.08,0.22]$ & 2014 & & 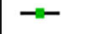 & \\
\hline Pattnaik 2015 & 0.95 & 0.2 & 20 & 0.93 & 0.22 & 20 & $15.8 \%$ & $0.02[-0.11,0.15]$ & 2015 & $\rightarrow$ & - & \\
\hline John 2015 & 1.45 & 0.22 & 10 & 0.8 & 0.16 & 10 & $14.8 \%$ & $0.65[0.48,0.82]$ & 2015 & & & \\
\hline Singh 2017 & 0.57 & 0.11 & 40 & 0.43 & 0.11 & 40 & $17.4 \%$ & $0.14[0.09,0.19]$ & 2017 & & 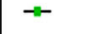 & \\
\hline Diwa 2018 & 1.13 & 0.07 & 61 & 0.63 & 0.08 & 61 & $17.5 \%$ & $0.50[0.47,0.53]$ & 2018 & & & $=$ \\
\hline \multirow{2}{*}{\multicolumn{10}{|c|}{$\begin{array}{l}\text { Total }(95 \% \mathrm{Cl}) \quad 156 \quad 156 \quad 100.0 \% \\
\text { Heterogeneity: } \text { Tau }^{2}=0.04 ; \mathrm{Chi}^{2}=262.19, \mathrm{df}=5(\mathrm{P}<0.00001) ; I^{2}=98 \% \\
\text { Test for overall efiect: } Z=3.83(\mathrm{P}=0.0001)\end{array}$}} & & & \\
\hline & & & & & & & & & & $\begin{array}{cc}-0.5 & + \\
\text { Favours SRP alone }\end{array}$ & Favours & $\begin{array}{c}0.5 \\
\text { SRP plus } \mathrm{CH} \times \text { chip }\end{array}$ \\
\hline
\end{tabular}


difference in CAL between the study groups at 1 month (MD 0.54), 3 months (MD 0.64), and 6 months (MD 0.68) with results favoring sites treated with $\mathrm{CHX}$ chip plus SRP. These findings concur with previous reviews on the topic. Smiley et al. [45] in a systematic review and meta-analysis published in 2015 have analyzed the efficacy of local adjuncts in combination with SRP. The inclusion criteria of this review were limited to studies with a minimum 6 months follow-up with CAL as primary outcome. After an analysis 6 RCTs, the authors reported a statistical significant increase of CAL (MD 0.4, 95\% CI 0.24-0.56) with the use of CHX chip as an adjunct to SRP as compared to SRP alone. However, no meta-analysis was performed for PPD in their study.

Another review by Matesanz Perez et al. [46] published in 2013 has investigated the effect of local antimicrobials as an adjunct to subgingival debridement in the management of chronic periodontitis. In a sub-group analysis, data from 9 trials assessing the efficacy of $\mathrm{CHX}$ chips as an adjunct to SRP was pooled [46]. The authors reported no statistical significant difference in PPD between the study groups at short-term follow-up $(<6$ months) $(p=0.321)$, but reported significantly better outcomes with CHX chips after a follow-up of 6-12 months) $(p<0.001)$. Similar findings were also recorded for change in CAL. The included studies also demonstrated significant heterogeneity in the PPD and CAL assessments [46]. Similarly, our meta-analysis also showed very high heterogeneity among the included studies in terms of the clinical parameters studied. This may be attributed to several factors like the variation in the study populations, disease severity, quality of SRP, operator's experience, etc. Such heterogeneity in the meta-analysis may cause over- or under-estimation of the treatment effect of the CHX chips, limiting the results of our systematic review.

While discussion the results of $\mathrm{CHX}$ as an adjunct to non-surgical therapy, it is important to distinguish the effects of various modes of delivery of $\mathrm{CHX}$. CHX chip has proved itself to be more effective as compared to other forms like CHX irrigation or gel [24].. Due to the slow degradation of the chip, CHX is released in a gradual and sustained manner for a longer period of time. In comparison, the gel form, though delivered locally in to the periodontal pocket, does not provide for sustained release of CHX. Similarly, CHX irrigation provides only a short-term effect due to the drugs substantivity of 12 h. Furthermore, the continuous flow of gingival crevicular fluid in the periodontal pocket hinders the retention of CHX solution.

One of the major limitations of this study is our failure to perform a meta-analysis for the assessment of periodontal pathogen colony count reductions and BOP due to unavailability of adequate trials assessing these variables. Other drawbacks include a lack of descriptions of SRP instruments (manual or ultrasonic scalers) as well as the duration of the instrumentation and operator variations. Another source of heterogeneity among the included studies is due to effects of multiple applications of CHX chips. One of the studies mentioned the use of second CHX chips to improve outcomes [22]. However, the placement of the second chip was made at the end of 6 months and would not have affected our metaanalysis results [22]. The results of the mentioned study were significantly better for sites with SRP and CHX chips than for sites with SRP alone, even after 9 months of follow-up, suggesting that multiple $\mathrm{CHX}$ chip applications could be of added benefit for long term effects [22]. Lastly, the quality of overall evidence was moderate as majority of the included studies did not provide details of allocation concealment, blinding of personnel and blinding of outcome assessors. This may have introduced bias in the overall results of our analysis.

The results of this review seem to indicate that the CHX chip may serve as a useful adjuvant to non-surgical periodontal therapy. However, the combination of CHX and SRP cannot be considered as a gold standard treatment. Due to better outcomes with CHX, the need for surgical therapy for treating periodontal pockets may be minimized. Clinicians should assess the need for surgery on a case-to-case basis while also considering the use of CHX chip with non-surgical therapy. The clinical outcomes with CHX chip as an adjunct to SRP also depend upon the baseline PPD, the adequacy of SRP as well as on the patient's compliance, systemic disease status, and smoking habit. These criteria's should be considered while recommending the use of $\mathrm{CHX}$ chips to treat periodontal pockets.

\section{Conclusion}

Within the study limitations, our results indicate that clinical outcomes may be significantly improved in patients undergoing non-surgical therapy for periodontal pockets with the adjunctive use of CHX chip after SRP as compared to SRP alone. The overall quality of evidence is moderate. Further trials focusing on microbiological outcomes are needed to assess the efficacy of $\mathrm{CHX}$ in reducing the load of periodontal pathogens.

\section{Abbreviations}

SRP: Scaling and root planing; CAL: Clinical attachment level; PPD: Probing pocket depth; CHX: Chlorhexidine

\section{Acknowledgments}

Not applicable.

Authors' contributions

LM designed the paper. LM and XD were involved in literature search, data interpreted and data analysis. LM prepared the manuscript. The authors have read and approved the final manuscript. 


\section{Funding}

Not applicable.

\section{Availability of data and materials}

The datasets used and/or analyzed during the current study are available from the corresponding author on reasonable request.

\section{Ethics approval and consent to participate}

Not applicable.

\section{Consent for publication}

Not applicable.

\section{Competing interests}

The authors declare that they have no competing interests.

\section{Author details}

'Department of stomatology, Zaozhuang Maternal and Child Health Hospital, Zaozhuang 277100, Shandong, China. ${ }^{2}$ Department of stomatology, Zaozhuang Hospital of Traditional Chinese Medicine, 2666 Taihangshan Road, Xuecheng District, Zaozhuang, Shandong 277000, P.R. China.

\section{Received: 15 February 2020 Accepted: 7 September 2020}

Published online: 21 September 2020

\section{References}

1. Guthmiller JM, Novak KF. Periodontal diseases: ASM Press; 2002. https:// www.ncbi.n/m.nih.gov/books/NBK2496/. Accessed 24 Dec 2019.

2. Panda S, Panda S, Das AC. Cytokines: the double edge sword for periodontal disease. Indian J Foren Med Toxicol. 2019;13:1931. https://doi. org/10.5958/0973-9130.2019.00603.0.

3. Del Fabbro M, Karanxha L, Panda S, Bucchi C, Nadathur Doraiswamy J, Sankari M, et al. Autologous platelet concentrates for treating periodontal infrabony defects. Cochrane Database Syst Rev. 2018;2018. https://doi.org/ 10.1002/14651858.CD011423.pub2.

4. Aimetti M. Nonsurgical periodontal treatment. Int J Esthet Dent. 2014:9:251-67.

5. Badersten A, Nilvéus R, Egelberg J. Effect of nonsurgical periodontal therapy. I. Moderately advanced periodontitis. J Clin Periodontol. 1981:8:57-72.

6. Badersten A, Nilveus R, Egelberg J. Effect of nonsurgical periodontal therapy. II. Severely advanced periodontitis. J Clin Periodontol. 1984;11:63-76.

7. Drisko CH. Nonsurgical periodontal therapy. Periodontol. 2001;25:77-88.

8. Isidor F, Karring T, Attström R. The effect of root planing as compared to that of surgical treatment. J Clin Periodontol. 1984;11:669-81.

9. Rateitschak-Plüss EM, Schwarz JP, Guggenheim R, Düggelin M, Rateitschak $\mathrm{KH}$. Non-surgical periodontal treatment: where are the limits? An SEM study. J Clin Periodontol. 1992;19:240-4.

10. Barca E, Cifcibasi E, Cintan S. Adjunctive use of antibiotics in periodontal therapy. J Istanb Univ Fac Dent. 2015;49:55-62. https://doi.org/10.17096/ jiufd.90144.

11. Jepsen K, Jepsen S. Antibiotics/antimicrobials: systemic and local administration in the therapy of mild to moderately advanced periodontitis. Periodontol. 2016:71:82-112.

12. Kinane DF. Local antimicrobial therapies in periodontal disease. Ann R Australas Coll Dent Surg. 2000;15:57-60.

13. Joshi D, Garg T, Goyal AK, Rath G. Advanced drug delivery approaches against periodontitis. Drug Deliv. 2016;23:363-77. https://doi.org/10.3109/ 10717544.2014.935531.

14. Kalsi R, Vandana KL, Prakash S. Effect of local drug delivery in chronic periodontitis patients: a meta-analysis. J Indian Soc Periodontol. 2011;15: 304-9. https://doi.org/10.4103/0972-124X.92559.

15. James $P$, Worthington HV, Parnell C, Harding M, Lamont $T$, Cheung A, et al. Chlorhexidine mouthrinse as an adjunctive treatment for gingival health. Cochrane Database Syst Rev. 2017. https://doi.org/10.1002/14651858. CD008676.pub2

16. García-Caballero L, Quintas V, Prada-López I, Seoane J, Donos N, Tomás I. Chlorhexidine Substantivity on salivary Flora and Plaque-like biofilm: an in situ model. PLoS One. 2013;8:e83522. https://doi.org/10.1371/journal.pone. 0083522.

17. Jagadish Pai BS, Rajan SA, Srinivas M, Padma R, Suragimath G, Walvekar A et al. Comparison of the efficacy of chlorhexidine varnish and chip in the treatment of chronic periodontitis. Contemp Clin Dent. 2013;4:156-61 https://doi.org/10.4103/0976-237X.114848.

18. Soskolne WA, Chajek T, Flashner M, Landau I, Stabholtz A, Kolatch B, et al. An in vivo study of the chlorhexidine release profile of the PerioChip in the gingival crevicular fluid, plasma and urine. J Clin Periodontol. 1998:25:1017-21.

19. Cosyn J, Wyn I. A systematic review on the effects of the chlorhexidine chip when used as an adjunct to scaling and root planing in the treatment of chronic periodontitis. J Periodontol. 2006;77:257-64.

20. Sahu B, Gathe B, Chandrakar J, Zade R, Khade A, Kamble RL. Efficacy of chlorhexidine chips as local drug delivery in non-surgical management of chronic periodontitis. Int Dent Med J Adv Res. 2019;5:1-4.

21. Singh M, Gupta R, Dahiya P, Kumar M, Bhardwaj R. Assessment of efficacy of chlorhexidine chip as an adjunct to scaling and root planning using $\mathrm{N}$ benzoyIDL-arginine-2-naphthylamide test kit. Asian Pacific J Health Sci. 2018; 5:111-5

22. Divya P, Nayar B, Nandakumar K. Clinical efficacy of sustained release chlorhexidine in collagen membrane in the non surgical management of chronic localised periodontitis. IOSR J Dental Med Sci. 2018:17:22-9.

23. Singh A, Sridhar R, Shrihatti R, Mandloy A. Evaluation of turmeric Chip compared with Chlorhexidine Chip as a local drug delivery agent in the treatment of chronic periodontitis: a Split mouth randomized controlled clinical trial. J Altern Complement Med. 2018;24:76-84.

24. Lecic J, Cakic S, Janjic Pavlovic O, Cicmil A, Vukotic O, Petrovic V, et al. Different methods for subgingival application of chlorhexidine in the treatment of patients with chronic periodontitis. Acta Odontol Scand. 2016; 74:502-7.

25. John P, Lazarus F, George JP, Selvam A, Prabhuji MLV. Adjunctive effects of a Piscean collagen-based controlled-release Chlorhexidine Chip in the treatment of chronic periodontitis: a clinical and microbiological study. J Clin Diagn Res. 2015;9:ZC70-4.

26. Pattnaik S, Anand N, Chandrasekaran SC, Chandrashekar L, Mahalakshmi K, Satpathy A. Clinical and antimicrobial efficacy of a controlled-release device containing chlorhexidine in the treatment of chronic periodontitis. Eur J Clin Microbiol Infect Dis. 2015;34:2103-10.

27. Kumar AJ, Reddy BR, Chava VK. Effect of chlorhexidine chip in the treatment of chronic periodontitis. J Natural Sci Biol Med. 2014;5:268. https://doi.org/ 10.4103/0976-9668.136159.

28. Medaiah S, Srinivas M, Melath A, Girish S, Polepalle T, Dasari AB. Chlorhexidine Chip in the treatment of chronic periodontitis - a clinical study. J Clin Diagn Res. 2014;8:ZC22-5. https://doi.org/10.7860/JCDR/2014/ 8808.4477.

29. Puri K, Dodwad V, Bhat K, Puri N. Effect of controlled-release Periochip ${ }^{\text {TM }}$ on clinical and microbiological parameters in patients of chronic periodontitis. J Indian Soc Periodontol. 2013;17:605-11. https://doi.org/10.4103/0972-124X. 119299

30. Grover V, Kapoor A, Malhotra R, Battu VS, Bhatia A, Sachdeva S. To assess the effectiveness of a chlorhexidine chip in the treatment of chronic periodontitis: a clinical and radiographic study. J Indian Soc Periodontol. 2011;15:139-46

31. Sakellari D, Dimitra S, loannidis I, loannis I, Antoniadou M, Malama A, et al. Clinical and microbiological effects of adjunctive, locally delivered chlorhexidine on patients with chronic periodontitis. J Int Acad Periodontol. 2010;12:20-6.

32. Paolantonio M, D'Angelo M, Grassi RF, Perinetti G, Piccolomini R, Pizzo G, et al. Clinical and microbiologic effects of subgingival controlled-release delivery of chlorhexidine chip in the treatment of periodontitis: a multicenter study. J Periodontol. 2008;79:271-82

33. Paolantonio $M$, Dolci M, Perfetti G, Sammartino G, D'Archivio D, Spoto $G$, et al. Effect of a subgingival chlorhexidine chip on the clinical parameters and the levels of alkaline phosphatase activity in gingival crevicular fluid during the non-surgical treatment of periodontitis. J Biol Regul Homeost Agents. 2008;22:63-72.

34. Konugati K, Kumar A. Efficacy of Subgingivally delivered Flurbiprofen and Chlorhexidine Chip in the treatment of chronic periodontitis - a randomized controlled clinical trial. Int J Pharmaceutical Sci Rev Res. 2016; 40:149-53.

35. Jhinger N, Kapoor D, Jain R. Comparison of Periochip (chlorhexidine gluconate $2.5 \mathrm{mg}$ ) and Arestin (minocycline hydrochloride $1 \mathrm{mg}$ ) in the management of chronic periodontitis. Indian J Dent. 2015:6:20-6. https:// doi.org/10.4103/0975-962X.151697. 
36. Singh M, Shreehari AK, Garg PK, Singh S. Clinical efficacy of chlorhexidine chips and tetracycline fibers as an adjunct to non surgical periodontal therapy. Eur J Gen Dent. 2014;3:134. https://doi.org/10.4103/2278-9626. 134840.

37. Kondreddy K, Ambalavanan N, Ramakrishna T, Kumar RS. Effectiveness of a controlled release chlorhexidine chip (PerioCol ${ }^{\mathrm{T}}-\mathrm{CG}$ ) as an adjunctive to scaling and root planing when compared to scaling and root planing alone in the treatment of chronic periodontitis: a comparative study. J Indian Soc Periodontol. 2012;16:553-7.

38. Machtei EE, Hirsh I, Falah M, Shoshani E, Avramoff A, Penhasi A. Multiple applications of flurbiprofen and chlorhexidine chips in patients with chronic periodontitis: a randomized, double blind, parallel, 2-arms clinical trial. J Clin Periodontol. 2011;38:1037-43.

39. Gonzales JR, Harnack L, Schmitt-Corsitto G, Boedeker RH, Chakraborty T, Domann $\mathrm{E}$, et al. A novel approach to the use of subgingival controlledrelease chlorhexidine delivery in chronic periodontitis: a randomized clinical trial. J Periodontol. 2011:82:1131-9.

40. Paul GT, Hemalata M, Faizuddin M. Modified Widman flap and non-surgical therapy using chlorhexidine chip in the treatment of moderate to deep periodontal pockets: a comparative study. J Indian Soc Periodontol. 2010;14: 252-6. https://doi.org/10.4103/0972-124X.76932.

41. Kasaj A, Chiriachide A, Willershausen B. The adjunctive use of a controlledrelease chlorhexidine chip following treatment with a new ultrasonic device in supportive periodontal therapy: a prospective, controlled clinical study. Int J Dent Hyg. 2007;5:225-31.

42. Stanley A, Wilson M, Newman HN. The in vitro effects of chlorhexidine on subgingival plaque bacteria. J Clin Periodontol. 1989;16:259-64.

43. Grenier D, Bertrand J, Mayrand D. Porphyromonas gingivalis outer membrane vesicles promote bacterial resistance to chlorhexidine. Oral Microbiol Immunol. 1995;10:319-20.

44. Laugisch O, Schacht M, Guentsch A, Kantyka T, Sroka A, Stennicke HR, et al. Periodontal pathogens affect the level of protease inhibitors in gingival crevicular fluid. Mol Oral Microbiol. 2012;27:45-56.

45. Smiley CJ, Tracy SL, Abt E, Michalowicz BS, John MT, Gunsolley J, et al. Systematic review and meta-analysis on the nonsurgical treatment of chronic periodontitis by means of scaling and root planing with or without adjuncts. J Am Dent Assoc. 2015:146:508-524.e5.

46. Matesanz-Pérez P, García-Gargallo M, Figuero E, Bascones-Martínez A, Sanz $M$, Herrera D. A systematic review on the effects of local antimicrobials as adjuncts to subgingival debridement, compared with subgingival debridement alone, in the treatment of chronic periodontitis. J Clin Periodontol. 2013:40:227-41.

\section{Publisher's Note}

Springer Nature remains neutral with regard to jurisdictional claims in published maps and institutional affiliations.

Ready to submit your research? Choose BMC and benefit from:

- fast, convenient online submission

- thorough peer review by experienced researchers in your field

- rapid publication on acceptance

- support for research data, including large and complex data types

- gold Open Access which fosters wider collaboration and increased citations

- maximum visibility for your research: over $100 \mathrm{M}$ website views per year

At $\mathrm{BMC}$, research is always in progress.

Learn more biomedcentral.com/submissions 